\title{
Review: avulsion with phenol prevents recurrence of ingrown toenails
}

Rounding C, Hulm S. Surgical treatments for ingrowing toenails. Cochrane Review, latest version 13 Mar 1999. In: Cochrane Library. Oxford: Update Software.

\section{QUESTION: In patients with ingrown toenails, how do various methods of surgical treatment compare with each other and with chemical treatments?}

\section{Data sources}

Studies were identified by searching the Cochrane Controlled Trials Register, Medline, EMBASE/Excerpta Medica, and CINAHL; schools of podiatry and manufacturers of cryotherapy, radiowave, and electrosurgical equipment were contacted; and reference lists of relevant studies were reviewed.

\section{Study selection}

Studies were selected if they were randomised or quasirandomised trials that compared 1 form of surgery with another or with other treatments that aimed to permanently remove all or part of an ingrown toenail and had $\geq 6$ months of follow-up.

\section{Data extraction}

Data were extracted on study quality (allocation concealment, intention-to-treat analysis, baseline comparability, and follow-up). Outcomes considered were regrowth, relief of symptoms, healing time, infection, postoperative pain, and patient satisfaction.

\section{Main results}

9 studies were included. 1 study that compared nail avulsion and phenol with nail avulsion alone showed that the addition of phenol reduced symptomatic recurrence $\{\mathrm{p}<0.001\}^{*}$ but increased the rate of postoperative infection $\{p=0.002\}^{*}$; fewer patients receiving phenolisation, however, were dissatisfied $\{\mathrm{p}<0.001\}^{*}$ (table). Avulsion with phenol reduced symptomatic recurrence ( 5 trials) $\{\mathrm{p}=0.008\} *$ more than did surgical

Avulsion with phenol (AvP) v avulsion (Av) or surgical excision (SE) for ingrown toenails $\dagger$

\begin{tabular}{|c|c|c|c|c|}
\hline $\begin{array}{l}\text { Outcomes at } \\
\geqslant 6 \text { months }\end{array}$ & AvP & Av & $\begin{array}{l}\text { RRR } \\
(95 \% \mathrm{Cl})\end{array}$ & NNT (Cl) \\
\hline $\begin{array}{r}\text { Symptomatic } \\
\text { recurrence }\end{array}$ & $11 \%$ & $77 \%$ & $\begin{array}{l}85 \% \\
(74 \text { to } 91)\end{array}$ & $\begin{array}{l}2 \\
\text { (2 to } 2)\end{array}$ \\
\hline \multirow[t]{2}{*}{$\begin{array}{l}\text { Patient } \\
\text { dissatisfaction }\end{array}$} & $16 \%$ & $53 \%$ & $\begin{array}{l}70 \% \\
\text { (52 to } 81 \text { ) }\end{array}$ & $\begin{array}{l}3 \\
\text { (3 to } 4)\end{array}$ \\
\hline & & & $\mathrm{RRI}(\mathrm{Cl})$ & $\mathrm{NNH}(\mathrm{Cl})$ \\
\hline \multirow[t]{3}{*}{$\begin{array}{c}\text { Postoperative } \\
\text { infection }\end{array}$} & $11 \%$ & $0.9 \%$ & $\begin{array}{l}722 \% \\
\text { (59 to } 4154)\end{array}$ & $\begin{array}{l}10 \\
(6 \text { to } 25)\end{array}$ \\
\hline & \multicolumn{2}{|c|}{$\begin{array}{l}\text { Weighted event } \\
\text { rates }\end{array}$} & & \\
\hline & $A v P$ & $S E$ & $R R R(C l)$ & $N N T(C l)$ \\
\hline $\begin{array}{l}\text { Symptomatic } \\
\text { recurrence }\end{array}$ & $5 \%$ & $11 \%$ & $\begin{array}{l}54 \% \\
(17 \text { to } 75)\end{array}$ & $\begin{array}{l}17 \\
(10 \text { to } 59)\end{array}$ \\
\hline $\begin{array}{l}\text { Postoperative } \\
\text { infection }\end{array}$ & $11.6 \%$ & $18 \%$ & $\begin{array}{l}35 \% \\
(-42 \text { to } 70)\end{array}$ & $\begin{array}{l}\text { Not } \\
\text { significant }\end{array}$ \\
\hline
\end{tabular}

excision, and treatments did not differ for postoperative infection (2 trials) $\{\mathrm{p}=0.28\}^{*}$ (table). Insufficient data were available to quantify other outcomes.

\section{Conclusions}

In patients with ingrown toenails, nail avulsion with phenol is more effective in preventing recurrence than avulsion alone or surgical excision. 1 study shows avulsion with phenol increases postoperative infection.

*p Values calculated from data in article.

\section{COMMENTARY}

The meta-analysis by Rounding and Hulm evaluates surgical methods for the treatment of ingrown toenails. The authors conclude that phenol with avulsion was superior to surgical excision for prevention of symptomatic recurrence but at the cost of increased rates of post-operative infection.

Surgical and carbolic acid (phenol) treatment of ingrown toenails has been used concurrently since 1901 or before. ${ }^{1}$ Both have been reported successful at permanently eradicating symptomatic ingrown toenails. Basic surgical principles deem it reasonable to hypothesise that surgical excision of the matrix by any of a number of techniques will consistently result in less postoperative inflammation than phenolisation, which, because of its caustic nature, has the potential to cause soft-tissue or bony infection. ${ }^{2}$ At least 1 author, however, maintains that the overall potential for complications with phenol or surgical treatment is similar.

Rounding and Hulm have done a good job of synthesising their conclusions in this review of a wide range of studies with different design criteria, inclusion parameters, and secondary outcome measures (ie, differences in healing times and degree of pain).

Because of the caustic nature of phenol, a priori use in medically immunocompromised or ischaemic patients should be contraindicated. However, Felton and Weaver state that phenol can be used in patients with diabetes mellitus. ${ }^{4}$

Rounding and Hulm's conclusions appear reasonable. The following 3 study parameters, however, should also be considered: the experience and professions of a representative sample of surgeons, the degree of infection in the ingrown toenail before treatment, and the age and medical history of the study patients.

If this review were expanded to include such treatments as negative galvanism, trephine, osteotrypsy, laser ablation, or sodium hydroxide or silver nitrate chemical cautery, different conclusions might be reached.

Allan S Goldberg, DPM St John's Episcopal Hospital Far Rockaway, New York, USA

1 Dagnall JC. The Foot 1991;1:51-5.

2 Caprioli R, Bilotti MA. Clin Podiatr Med Surg 1989;6:431-51. 3 Kuwada GT. J Am Podiatr Med Assoc 1991;81:33-6.

4 Felton PM, Weaver TD. J Am Podiatr Med Assoc 1999;89:410-2. 